Duke of Edinburgh, president of the Society, at the annual general meeting on May 4: Scientific Medal (awarded to persons under forty years of age for scientific merit and distinguished work in zoology), to Dr. L. Brent, the National Institute for Medical Research, Mill Hill, N.W.7, who has worked with Dr. P. B. Medawar and Dr. R. E. Billingham on transplantation immunology; to Dr. P. H. Greenwood, principal scientific officer, Department of Zoology, British Museum (Natural History), for outstanding work on the life-histories of East African freshwater fishes and in particular on the taxonomy and relationships of African spezies of cichlid fishes; and to Dr. Janet Harker, of the Department of Zoology, University of Cambridge, for her work on the physiology of the sense of time and the basis of periodic activities in lower animals. Stamford Raffles Award, to C. W. MackworthPraed, of Castle Top, Burley, Hampshire, in recognition of his distinguished contributions, as an amateur zoologist, to ornithology. Thomas Henry Huxley Award, to Dr. Charles Hugh O'Neill, of King's College, for original work submitted as a doctor's thesis to the University of London, on the "isolation and some properties of the cell surface membrane of Amoeba proteus". A Certificate of Commendation has also been awarded to Dr. Leonard Hill, of the Department of Zoology, University of Sheffield, for his thesis on "Endocrine Control of Oocyte Development in the Desert Locust Schistocerca gregaria". Prince Philip Prize (open for competition to pupils of zoology, taking the General Certificate of Education Advanced Level or equivalent examination in any school in Great Britain, Northern Ireland, the Channel Isles or Isle of Man on the basis of a well-illustrated essay on animal ecology or behaviour), to Janice Cornell (aged nineteen years), of the County Grammar School for Girls, Potters Lane, Lewes, Sussex, for her entry, "The Relationship between Light Intensity and Temperature on the Horizontal Veloeity of Polycelis nigra (Ehrenberg)".

\section{The Institute of Metals: Awards}

THE Council of the Institute of Metals has announced the awards of the following medals: The Institute of Metals (Platinum) Medal for 1964, to Sir Geoffrey Taylor. Fellow of Trinity College, Cambridge, in recognition of his outstanding contributions over a wide field which have included considerable contributions to metallurgical science; The Rosenhain Medal for 1964, to Dr. R. S. Barnes, head of the Irradiation Branch. Metallurgy Division, Atomic Energy Research Establishment, Harwell, in recognition of his outstanding contributions in the field of physical metallurgy; $W$. H. A. Robertson Medal and Premium for 1963, jointly to R. J. Elger (Loewy Engineering Co., Ltd.) and A. R. Martin (Alcan Industries, Ltd.), for papers contributed to the Journal on engineering aspects of non-ferrous metallurgy.

\section{The Night Sky in March}

New moon occurs on Mar. 14d $02 \mathrm{~h} 14 \mathrm{~m}$ U.T. and full moon on Mar. $28 \mathrm{~d} 02 \mathrm{~h} 49 \mathrm{~m}$. The following conjunction with the Moon occurs: Mar 17d 06h, Venus $6^{\circ} \mathrm{N}$. Mercury is in conjunction with Jupiter on Mar. 31d 23h, Mereury being $3^{\circ} \mathrm{N}$. Mercury is an evening star, but is too close to the Sun for easy observation. Venus is an evening star, favourably situated for observation, setting at $21 \mathrm{~h}$ $40 \mathrm{~m}, 22 \mathrm{~h} 25 \mathrm{~m}$ and $23 \mathrm{~h} 05 \mathrm{~m}$ on March 1,15 and 31 , respectively. Its stellar magnitude is -3.8 ; its distance decreases during the month from 94 to 73 million miles, and the visible portion of the apparent disk from 0.693 to $0 \cdot 559$. Mars is too close to the Sun for observation. Jupiter sets at $21 \mathrm{~h} 15 \mathrm{~m}, 20 \mathrm{~h} 40 \mathrm{~m}$ and $20 \mathrm{~h} 00 \mathrm{~m}$ at the beginning. middle and end of the month, respectively. Its stellar magnitude is $\mathbf{- 1 \cdot 6}$ and its distance from the Earth on March 15 is 540 million miles. It is now unfavourably situated for observation. Saturn is too close to the Sun for observation. Occultations of stars brighter than magnitude 6 are as follows, observations being made at Greenwich: Mar. $2 \mathrm{~d} 00 \mathrm{~h} 50 \cdot 6 \mathrm{~m}, 80 \mathrm{Vir} .(R)$; Mar. $19 \mathrm{~d}$ 23h $14 \cdot 7 \mathrm{~m}, 106$ Tau. $(D)$; Mar. 2Id $21 \mathrm{~h} 15.5 \mathrm{~m}, 44$ Gem. $(D)$; Mar. $22 \mathrm{~d} 22 \mathrm{~h} 24 \cdot 3 \mathrm{~m}, \mu$ Cnc. $(D) . \quad R$ and $D$ refer to reappearance and disappearance, respectively. The vernal equinox occurs on Mar $20 \mathrm{~d} 14 \mathrm{~h} 10 \mathrm{~m}$.

\section{British Aid to Developing Countries}

IN a note, "British Aid to Developing Countries" (Nature, 200,1053; 1963), summarizing a recent White Paper from the Department of Technical Co-operation, it was not made clear that the assistance provided in geology and related matters comes from the Overseas Geological Surveys and not from the Directorate of Overseas (Geodetic and Topographical) Surveys. The words "By the Overseas Geological Survey" should accordingly be inserted in the last sentence of the penultimate paragraph, following "provided" and preceding "in geology". The oversight is regretted, but it should be noted that the White Paper does not make it explicit that Overseas Geological Surveys is a separate department and not part of the Directorate of Overseas (Geodetic and Topographical) Surveys. The reference number of the White Paper "Aid to Developing Countries" is Cmnd. 2147 and not 2137.

\section{Announcements}

A symposium on "Biosynthetic Pathways in Higher Plants", organized by the Plant Phenolies Group, will be held in the University of Leeds during April 13-15. Further information can be obtained from $\mathrm{Mr}$. A. H. Williams, Research Station, Long Ashton, Bristol.

AN international conference on "Mirids and Other Pests of Cocoa" will be held at the West African Cocoa Research Institute, Nigeria, during March 24-27. Further information can be obtained from Mr. P. F. Entwistle, West African Cocoa Research Institute, P.M.B. 5244, Moor Plantation, Ibadan.

The sixteenth conference of the British Occupational Hygiene Society entitled "Metals in Industry" will be held in the University of Manchester during April 7-8. Further information can be obtained from Dr. J. S. MeLintock, National Coal Board Medical Service, Hobart House, Grosvenor House, London, S.W.1.

A symposium on "Cold Cathode Tubes and their Applications", arranged by the British Institution of Radio Engineers, will be held in the University of Cambridge during March 16-19. The symposium will include sessions on: physies of operation and tube development; circuit design and reliability; applications of cold-cathode tubes. Further information can be obtained from the British Institution of Radio Engineers, 8--9 Bedford Square, London, W.C.l.

THE spring meeting of the Institute of Metals will be held in London during March 16-20. The programme will include sessions on: automatic controls and their applications; the metallurgy of high-field superconductors; high-strain fatigue; joining processes in reactor components; effluent treatment in the non-ferrous metal industries; heating of non-ferrous billets. A session of the Deutsche Gesellschaft für Metallkunde will also be held. The May Lecture entitled "The Nuclear Fuel Element: an Exercise in Metallurgy" will be delivered by Dr. H. M. Finniston. Further information can be obtained from the Secretary, Institute of Metals, 17 Belgrave Square, London, S.W.1.

Erratum. The American publisher of Erasmus Durwin. by D. G. King-Hele, which was reviewed on p. 536 of the February 8 issue of Nature, is Charles Seribner's Sons, New York, and not St. Martin's Press, Inc., as stated. 